\title{
Analisis Jalur Kualitas Sistem Terhadap Kepuasan Pengguna dan Intensitas Pengguna SIMRS Dengan Metode De Lone dan Mc Lean di Rumah Sakit Balung Kabupaten Jember \\ Analysis of System Quality Path on User Satisfaction and User Intensity of SIMRS Users With De Lone and Mc Lean Methods at Jember Balung Hospital
}

\section{Dony Setiawan H P ${ }^{1}$, Trismayanti Dwi Puspitasari ${ }^{2}$, Moch.Choirur Roziqin ${ }^{3}$}

Politeknik Negeri Jember; Jl. Mastrip PO BOX 164, (0331) 333532

Program Studi Rekam Medis, Jurusan Kesehatan, Politeknik Negeri Jember

Program Studi Teknik Informatika, Jurusan Teknologi Informasi, Politeknik Negeri Jember e-mail: ${ }^{1}$ donssend@gmail.com, ${ }^{2}$ trismayantidwipuspitasari@gmail.com,

${ }^{3}$ choirur_roziqin@yahoo.co.id

\begin{abstract}
Abstrak
Sistem informasi manajemen rumah sakit merupakan suatu usaha untuk menyajikan informasi yang akurat, tepat waktu dan sesuai kebutuhan guna menunjang proses fungsi-fungsi manajemen dan pengambilan keputusan dalam memberikan pelayanan kesehatan di Rumah Sakit. Masalah yang dihadapi oleh pengguna sistem informasi manajemen rumah sakit di Rumah Sakit Balung Kabupaten Jember didapatkan dari hasil wawancara, antara lain: kualitas sistem, kualitas informasi, kualitas layanan, intensitas pengguna, pengguna sistem, kepuasan pengguna dan netbenefit. Penelitian ini adalah penelitian analitik kuantitatif dengan menggunakan uji analisis jalur. Penelitian ini menilai persepsi pengguna sistem informasi manajemen rumah sakit dengan metode DeLone dan McLean. Peneliti menggunakan metode DeLone dan McLean karena metode tersebut cocok dengan karakteristik masalah yang ada di Rumah Sakit Balung Kabupaten Jember. Hasil dari penelitian ini adalah peneliti dapat mengetahui bahwa efek langsung standarized solution KS-IP=0,58. Sedangkan efek tidak langsung standarized solution KS-KP$\mathrm{IP}=0,78 \times 0,45=0,351$. Sehingga dapat ditarik kesimpulan bahwa dari analisis jalur bahwa efek langsung standarized solution KS-IP=0,58 > efek tidak langsung standarized solution KS-KP$\mathrm{IP}=0,78 \times 0,45=0,351$. Yang berarti memiliki makna jalur KS-IP lebih baik/lebih besar nilainya daripada KS-KP-IP.
\end{abstract}

Kata kunci- Intensitas Pengguna, Kepuasan Pengguna, kualitas sistem, Sistem Informasi Manajemen Rumah Sakit.

\section{Abstract}

A hospital management information system is an effort to present information accurately, timely and in accordance with the need to support the process of management functions and decision-making in providing health services in the Hospital. The interview result showed that the problem faced by users of the hospital management information system at Balung Hospital, Jember District, are system quality, information quality, service quality, user intensity, system user, user satisfaction and net-benefit. This research is quantitative analytical research by using path analysis test. This study exmaines the user perception of the hospital management information system with DeLone and McLean method. Those methods were used because they fit with the characteristics of existing problems at Balung Hospital Jember regency. Result of this research is researcher can know that direct effect standarized solution $K S-I P=0,58$. While the indirect effect of standarized solution $K S-K P-I P=0.78 \times 0,45=0.351$. So it can be concluded that from path analysis that the direct effect of standarized solution $K S-I P=0.58>$ indirect effect 
standarized solution $K S-K P-I P=0.78 \times 0,45=0.351$. Which means having a KS-IP path meaning better / greater value than KS-KP-IP.

Keywords - User Intensity, User Satisfaction, system quality, Hospital Management Information System

\section{PENDAHULUAN}

Pengelolaan data di rumah sakit merupakan salah satu komponen yang penting dalam mewujudkan suatu sistem informasi manajemen di rumah sakit. Pengelolaan data secara manual, mempunyai banyak kelemahan, selain membutuhkan waktu yang lama, keakuratannya juga kurang dapat diterima, karena kemungkinan kesalahan sangat besar. Dengan dukungan teknologi informasi yang ada sekarang ini, pekerjaan pengelolaan data dengan cara manual dapat digantikan dengan suatu sistem informasi dengan menggunakan komputer. Selain lebih cepat dan mudah, pengelolaan data juga menjadi lebih akurat. Survey pendahuluan tentang sistem informasi manajemen rumah sakit yang dilakukan peneliti di RS Balung Kabupaten Jember pada tanggal 15 Juni 2017. Peneliti melakukan wawancara dengan kepala Instalasi Sistem Informasi Rumah Sakit, Rawat Darurat, Rawat Inap, OK, ICU, Laboratorium, Radiologi yang berjumlah 7 orang terkait dengan sistem informasi manajemen rumah sakit. Hasil dari wawancara tersebut didapatkan informasi bahwa semua instalasi di rumah sakit telah mengimplementasikan sistem informasi manajemen rumah sakit. Masalah yang dihadapi oleh pengguna sistem informasi manajemen rumah sakit didapatkan dari hasil wawancara, antara lain: 1) Kualitas Sistem: tidak kompatibelnya sistem dengan proses pemberian layanan pada pasien. Contohnya petugas di IRD akan memasukkan data hasil pemeriksaan Airway, Breathing, Circulation, Dissability, Exposure pada sistem informasi manajemen rumah sakit. Tetapi isian pada template sistem informasi manajemen rumah sakit tidak ada. Data ini sangan dibutuhkan untuk melakukan penanganan terhadap pasien; 2) Intensitas Pengguna dan Pengguna Sistem: pengguna tidak mengimplementasikan sistem informasi manajemen rumah sakit dengan tablet (HP android) yang sudah disediakan oleh pihak manajemen rumah sakit. Contohnya dokter spesialis saat melakukan visite wajib mengisi resum medis dan hasil SOAP dengan menginputkan data hasil visite pasien ke dalam sistem informasi manajemen rumah sakit melalui tablet (HP Android). Namun pada kenyataannya proses tersebut hanya berjalan 1-2 bulan kemudian tidak diisi lagi oleh dokter tersebut karena menurut dokter spesialis tersebut pekerjaannta menjadi tambah lama dan kesulitan melakukan input data hasil visite pasien. Proses yang awalnya sudah menerapkan asuhan medis elektronik kembali ke manual; 3) Kepuasan pengguna: hasil survey peneliti secara subyektifitas dari pengguna sistem informasi manajemen rumah sakit dari 7 orang kepala instalasi menyatakan puas 2 orang dan yang tidak puas 5 orang. Dari masalah diatas muncul dampak negatif yang dirasakan oleh pihak rumah sakit. Dampak negatifnya adalah kualitas informasi yang dihasilkan oleh sistem informasi manajemen rumah sakit tidak berkualitas. Informasi dikatakan tidak berkualitas jika informasi tidak cepat, tidak lengkap, tidak akurat, tidak relevan. Berdasarkan masalah dan dampak negatif diatas terkait dengan sistem informasi manajemen rumah sakit peneliti memiliki solusi untuk menyelesaikan masalah tersebut dengan cara melakukan analisis implementasi sistem informasi manajemen rumah sakit dengan metode DeLone dan McLean. Metode DeLone dan McLean digunakan untuk mendeskripsikan dan menganalisis kualitas sistem, kualitas informasi, kualitas layanan, intensitas pengguna, pengguna sistem, kepuasan pengguna dan net-benefit. Dari penjelasan diatas peneliti memilih metode DeLone dan McLean karena sesuai dengan karakteristik masalah yang ada di Rumah Sakit Balung Jember yaitu kualitas sistem, kualitas informasi, kualitas layanan, intensitas pengguna, pengguna sistem dan kepuasan pengguna. Sesuai dengan hasil penelitian [1] tentang keefektifan portal akademik menunjukkan bahwa kualitas sistem, kualitas informasi, kualitas layanan berpengaruh signifikan terhadap kepuasan pengguna sistem informasi manajemen. Penelitian sebelumnya juga menunjukan serta sesuai dengan hasil penelitian DeLone dan McLean berpendapat bahwa ada beberapa hal penting 
yang mendorong diperlukannya teknologi informasi di organisasi. Hal ini berkaitan dengan proses pengambilan keputusan yang tidak dilandasi informasi, informasi yang tersedia tidak relevan, informasi yang ada tidak dimanfaatkan oleh manajemen, informasi yang ada tidak tepat waktu, terlalu banyak informasi, informasi yang tersedia tidak akurat, adanya data yang cara pemanfaatannya tidak fleksibel [2]. Pada penelitian sebelumnya [3] juga menunjukan Semakin baik persepsi kualitas sistem akan semakin meningkatkan kepuasan pengguna dan juga penelitian [4] menunjukan bahwa kualitas sistem, kualitas informasi, kualitas layanan berpengaruh signifikan terhadap kepuasan pengguna sistem informasi manajemen. Perbedaan penelitian ini dengan penelitian sebelumnya [5] adalah variabel yang digunakan dan tempat penelitian yang berbeda.

Berdasarkan hal tersebut maka dibutuhkan suatu sistem informasi yang mampu mendukung dalam pengambilan keputusan. Dalam hal ini ruang lingkup peneliti menggunakan metode DeLone dan Mclean yang terdiri dari 7 variabel. Namun saat ini peneliti akan melakukan penelitian pada 3 variabel saja karena variabel yang lain telah diteliti oleh peneliti sendiri pada tahun 2016 dan artikelnya masuk ke dalam jurnal penelitian inovasi Politeknik Negeri Jember.

\section{METODE PENELITIAN}

Jenis penelitian ini adalah penelitian analitik kuantitatif dengan pendekatan crossectional. Metode penelitian analitik kuantitatif adalah penelitian yang berlandaskan pada filsafat positivisme, digunakan untuk meneliti pada populasi atau sampel tertentu. Penentuan sampel pada umumnya dilakukan secara probability sampling, pengumpulan data menggunakan instrumen penelitian, analisis data bersifat kuantitatif atau statistik dengan tujuan untuk menguji hipotesis yang telah ditetapkan [6]. Penelitian ini tergolong kuantitatif karena analisis datanya bersifat kuantitatif.Gambar 2.

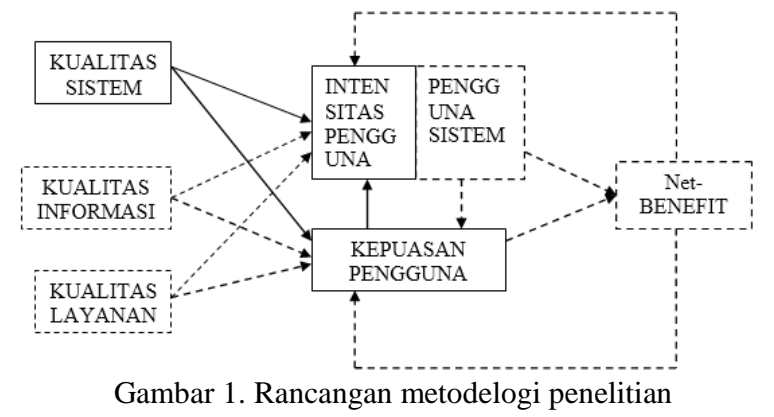

Hipotesis Penelitian

$\mathrm{H} 1=\mathrm{H} 1$ : Menganalisis kualitas sistem terhadap kepuasan pengguna sistem informasi Rumah Sakit Balung Kabupaten Jember

$\mathrm{H} 2=\mathrm{H} 1$ : Menganalisis kepuasan pengguna terhadap intensitas pengguna sistem informasi Rumah Sakit Balung Kabupaten Jember

H3=H1 : Menganalisis kualitas sistem terhadap intensitas pengguna sistem informasi Rumah Sakit Balung Kabupaten Jember

Populasi penelitian adalah keseluruhan objek penelitian atau objek yang diteliti. Populasi dalam penelitian ini adalah seluruh pengguna Sistem Informasi Manajemen Rumah Sakit yang dibagi menjadi 3 hak akses. Total keseluruhan populasi di Rumah Sakit Balung Kabupaten Jember pada tahun 2018 sejumlah 137 orang. Dengan sampel adalah objek yang diteliti dan mewakili keseluruhan populasi [7]. Sampel dalam penelitian ini adalah sebagian pengguna Sistem Informasi Manajemen Rumah Sakit Balung Kabupaten Jember pada tahun 2017. Besar sampel untuk penelitian ini dapat dihitung dengan menggunakan rumus Slovin, sebagai berikut : 


$$
\begin{aligned}
n & =\frac{\mathrm{N}}{1+\mathrm{N}\left(\mathrm{d}^{2}\right)} \ldots \ldots \ldots \ldots \ldots \ldots \ldots \ldots(3.1) \\
\mathrm{n} & =135 / 1+137(0,05) 2 \\
\mathrm{n} & =135 / 1+137(0,0025) \\
\mathrm{n} & =135 / 1,342 \\
\mathrm{n} & =102,08=103 \\
\text { keterangan: } & \\
\mathrm{N} & =\text { besar populasi } \\
\mathrm{n} & =\text { besar sampel } \\
\mathrm{d} & =\text { tingkat kepercayaan yang diinginkan }(5 \%)
\end{aligned}
$$

Teknik pengambilan sampel dalam penelitian ini menggunakan jenis probability sampling dengan teknik disproportionate stratified random sampling. Teknik ini digunakan untuk menentukan jumlah sampel bila populasinya berstrata tetapi kurang proporsional [6].

Kriteria inklusi :

a. Bersedia menjadi responden penelitian dengan menandatangani informed consent

b. Menggunakan sistem informasi manajemen rumah sakit di RS Balung Kabupaten Jember.

Kriteria eksklusi :

a. Responden mengundurkan diri

b. Respopnden tidak melakukan pengisian kuesioner.

Variabel dalam penelitian ini diklasifikasikan ke dalam variabel eksogen (independent) dan endogen (dependent)

a. Variabel eksogen (independent variabel)

Variabel eksogen terdiri atas kualitas sistem.

b. Variabel endogen (dependent variabel)

Variabel endogen adalah intensitas pengguna.

c. Variabel antara

Variabel endogen adalah kepuasan pengguna.

Dengan tabel 1 definisi operasional sebagai indicator terhadap instrument

Tabel 1. Definisi Tabel Operasional

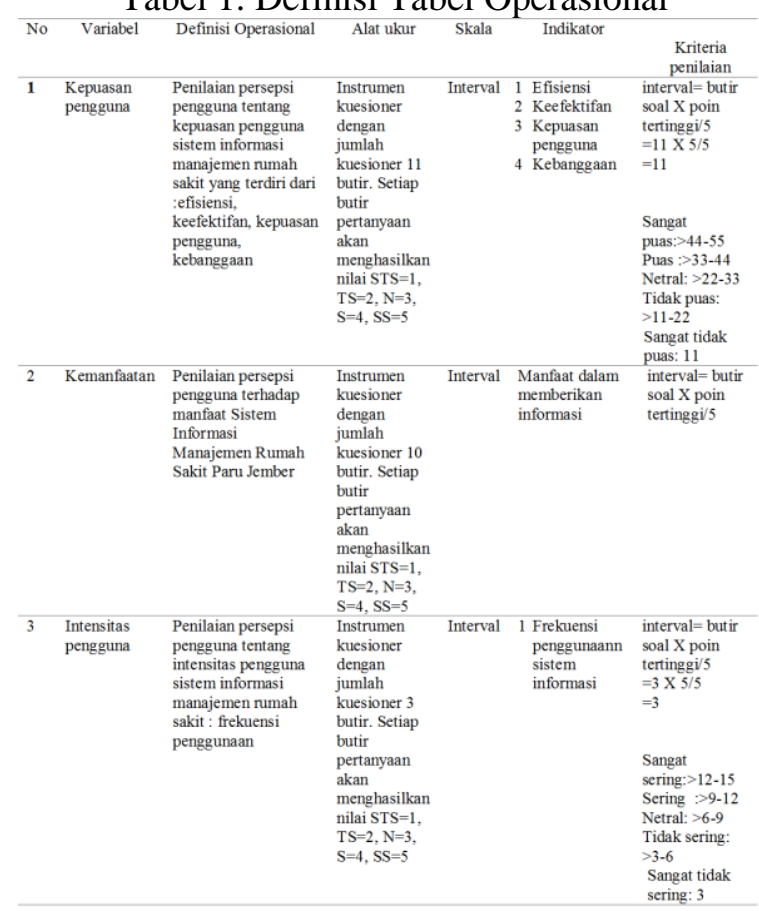


Teknik penyajian data dalam penelitian adalah dengan mendeskripsikan hasil identifikasi 3 variabel yang terdiri dari kualitas sistem, kepuasan pengguna dan intensitas pengguna dan menganalisis pengaruh 3 variabel tersebut. Analisis data yang digunakan dalam penelitian ini untuk menguji pengaruh antar variabel. Teknik analisis data dalam penelitian ini menggunakan analisis jalur. Langkah-langkah dalam melakukan uji regresi linier berganda:

1) Melakukan uji validitas dan reliabilitas

a) Validitas, adalah sejauh mana ketepatan dan kecermatan suatu alat ukur dalam melakukan fungsi ukurnya [8].Valid berarti instrumen tersebut dapat digunakan untuk mengukur apa yang seharusnya diukur.

b) Reliabilitas adalah indeks yang menunjukkan sejauh mana suatu alat pengukur dipercaya atau dapat diandalkan. Bila suatu alat ukur dipakai dua kali untuk mengukur gejala yang sama dan hasil pengukuran yang diperoleh relatif konsisten, maka alat ukur tersebut reliabel. Atau dengan kata lain, reliabilitas menunjukkan konsistensi suatu alat ukur di dalam mengukur gejala yang sama.

2) Pengujian Hipotesis, Pengujian hipotesis menggunakan analisis jalur karena ingin mengetahui adakah pengaruh langsung dari variabel eksogen kualitas sistem terhadap endogen intensitas pengguna.

\section{HASIL DAN PEMBAHASAN}

Hasil deskriptif Kualtas Sistem (KS), Kepuasan Pengguna (KP), Intensitas Pengguna (IP)

Tabel 3. Hasil Statistik Penelitian

\begin{tabular}{|l|r|r|r|}
\hline & KS & \multicolumn{1}{c|}{ KP } & \multicolumn{1}{c|}{ IP } \\
\hline N Valid & 103 & 103 & 103 \\
\multicolumn{1}{|c}{ Missing } & 22 & 22 & 22 \\
Mean & 64.54 & 46.23 & 12.96 \\
Median & 65.00 & 46.00 & 13.00 \\
Mode & $62^{\mathrm{a}}$ & 43 & 15 \\
Std. Deviation & 3.380 & 4.319 & 1.975 \\
Minimum & 52 & 39 & 9 \\
Maximum & 70 & 55 & 15 \\
Sum & 6648 & 4762 & 1335 \\
\hline
\end{tabular}

a. Multiple modes exist. The smallest

value is shown

Tabel 4. Hasil Dskriptif Kualitas Sistem

\begin{tabular}{|c|c|c|c|c|c|}
\hline & & $\begin{array}{c}\text { Frequenc } \\
\mathrm{y}\end{array}$ & Percent & $\begin{array}{c}\text { Valid } \\
\text { Percent }\end{array}$ & $\begin{array}{c}\text { Cumulative } \\
\text { Percent }\end{array}$ \\
\hline \multirow[t]{3}{*}{ Valid } & 52 & 1 & .8 & 1.0 & 1.0 \\
\hline & 58 & 1 & .8 & 1.0 & 1.9 \\
\hline & 59 & 4 & 3.2 & 3.9 & 5.8 \\
\hline
\end{tabular}

40 
Tabel 3. Hasil Statistik Penelitian

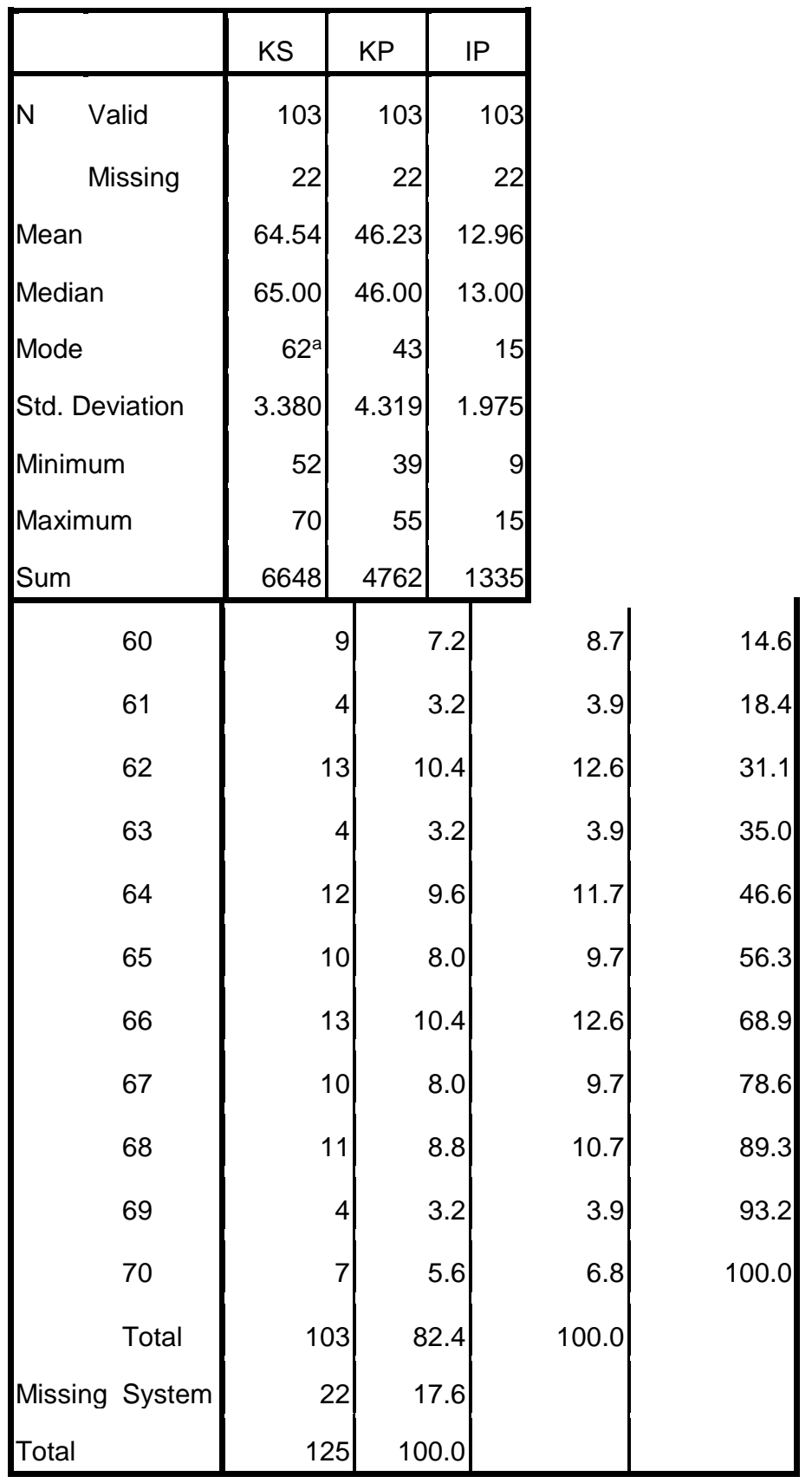




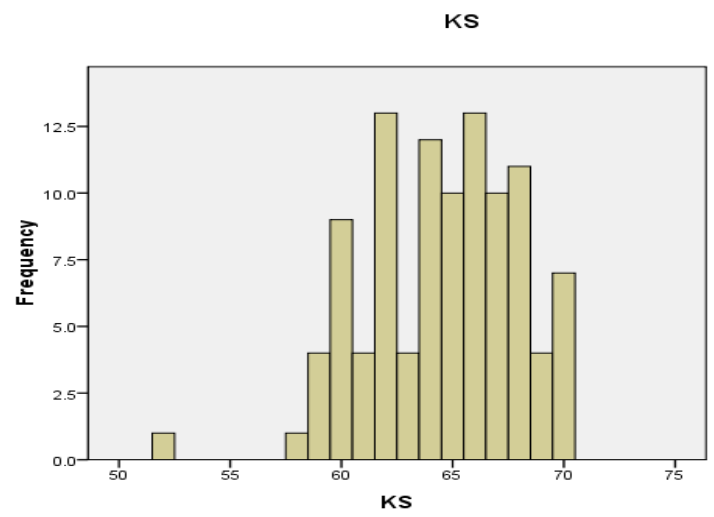

Gambar 2. Grafik Frekuensi Kualitas Sistem

Tabel 5. Hasil Deskriptif Kepuasan Pengguna

\begin{tabular}{|c|c|c|c|c|c|}
\hline & & Frequency & Percent & $\begin{array}{c}\text { Valid } \\
\text { Percent }\end{array}$ & $\begin{array}{c}\text { Cumulative } \\
\text { Percent }\end{array}$ \\
\hline \multirow[t]{18}{*}{ Valid } & 39 & 2 & 1.6 & 1.9 & 1.9 \\
\hline & 40 & 9 & 7.2 & 8.7 & 10.7 \\
\hline & 41 & 7 & 5.6 & 6.8 & 17.5 \\
\hline & 42 & 5 & 4.0 & 4.9 & 22.3 \\
\hline & 43 & 12 & 9.6 & 11.7 & 34.0 \\
\hline & 44 & 2 & 1.6 & 1.9 & 35.9 \\
\hline & 45 & 10 & 8.0 & 9.7 & 45.6 \\
\hline & 46 & 8 & 6.4 & 7.8 & 53.4 \\
\hline & 47 & 9 & 7.2 & 8.7 & 62.1 \\
\hline & 48 & 7 & 5.6 & 6.8 & 68.9 \\
\hline & 49 & 6 & 4.8 & 5.8 & 74.8 \\
\hline & 50 & 7 & 5.6 & 6.8 & 81.6 \\
\hline & 51 & 5 & 4.0 & 4.9 & 86.4 \\
\hline & 52 & 4 & 3.2 & 3.9 & 90.3 \\
\hline & 53 & 5 & 4.0 & 4.9 & 95.1 \\
\hline & 54 & 1 & .8 & 1.0 & 96.1 \\
\hline & 55 & 4 & 3.2 & 3.9 & 100.0 \\
\hline & Total & 103 & 82.4 & 100.0 & \\
\hline Missing & System & 22 & 17.6 & & \\
\hline Total & & 125 & 100.0 & & \\
\hline
\end{tabular}


KP

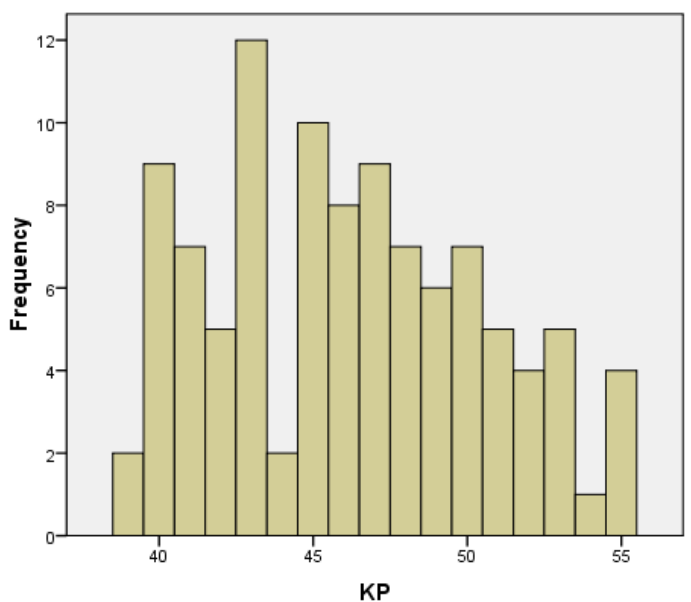

Mean $=46.23$
Std. Dev. $=4.319$
$N=103$

Gambar 3. Grafik Frekuensi Kepuasan Pengguna

Tabel 6. Hasil Deskriptif Intensitas Pengguna

\begin{tabular}{|c|c|c|c|c|c|}
\hline & & Frequency & Percent & Valid Percent & $\begin{array}{c}\text { Cumulative } \\
\text { Percent }\end{array}$ \\
\hline \multirow[t]{8}{*}{ Valid } & 9 & 4 & 3.2 & 3.9 & 3.9 \\
\hline & 10 & 14 & 11.2 & 13.6 & 17.5 \\
\hline & 11 & 9 & 7.2 & 8.7 & 26.2 \\
\hline & 12 & 12 & 9.6 & 11.7 & 37.9 \\
\hline & 13 & 18 & 14.4 & 17.5 & 55.3 \\
\hline & 14 & 8 & 6.4 & 7.8 & 63.1 \\
\hline & 15 & 38 & 30.4 & 36.9 & 100.0 \\
\hline & Total & 103 & 82.4 & 100.0 & \\
\hline Missing & System & 22 & 17.6 & & \\
\hline Total & & 125 & 100.0 & & \\
\hline
\end{tabular}




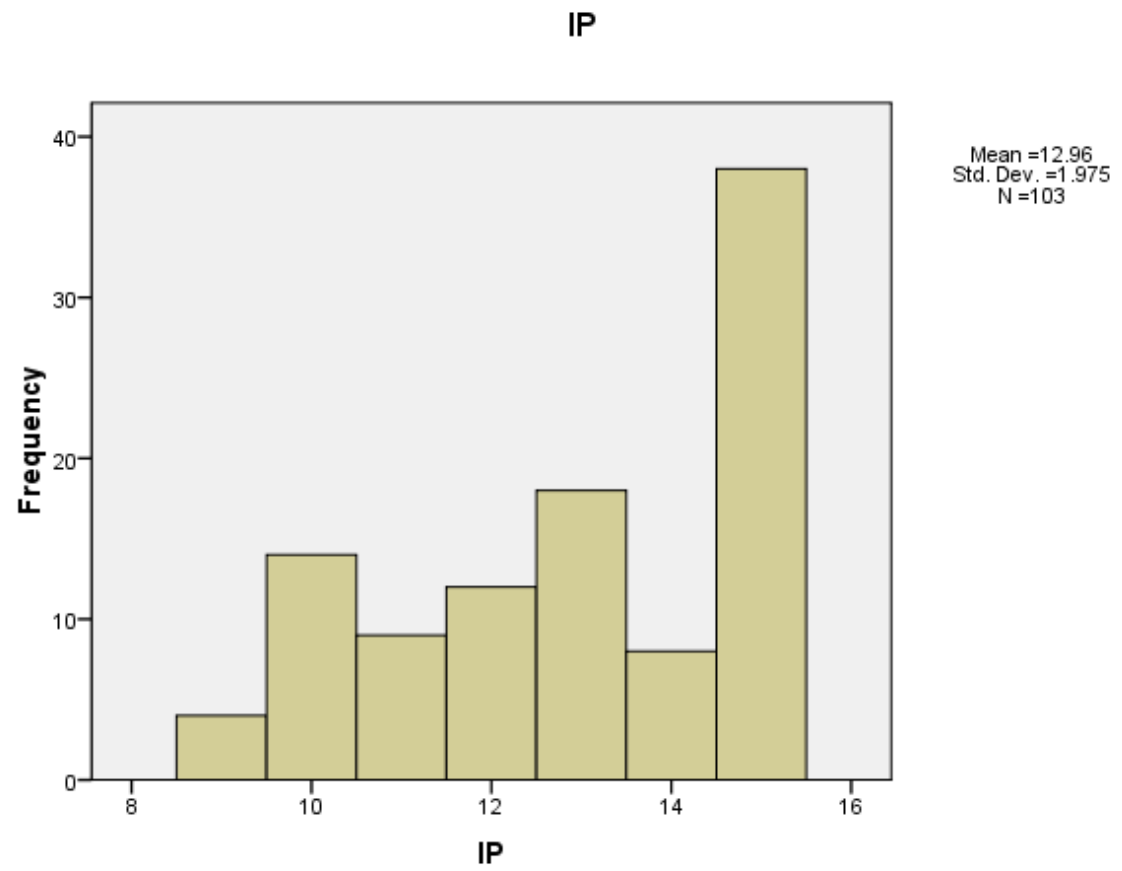

Gambar 4. Grafik Frekuensi Intensitas Pengguna

Hasil uji analisis jalur pada analisis sistem informasi manajemen rumah sakit dengan metode DeLone dan McLean di Rumah Sakit Daerah Balung Jember dengan menggunakan bantuan program LISREL 9.30.

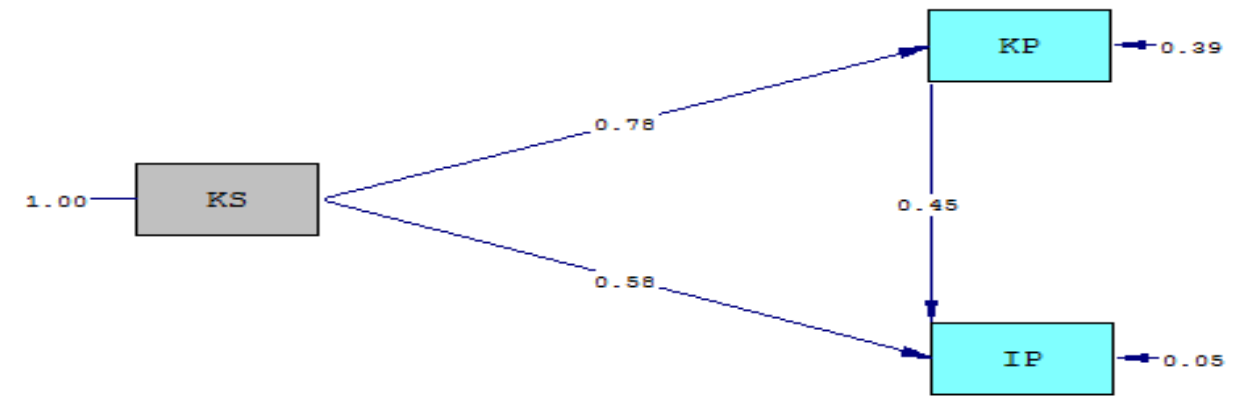

Chi-Square=0.00, df=0. P-value=1.00000. RMSEA=0.000

Gambar 5. Standarized Solution

Gambar 5 merupakan standardized solution untuk menunjukkan besarnya pengaruh kualitas sistem terhadap kepuasan pengguna, kepuasan pengguna terhadap intensitas pengguna dan kualitas sistem terhadap intensitas pengguna. 


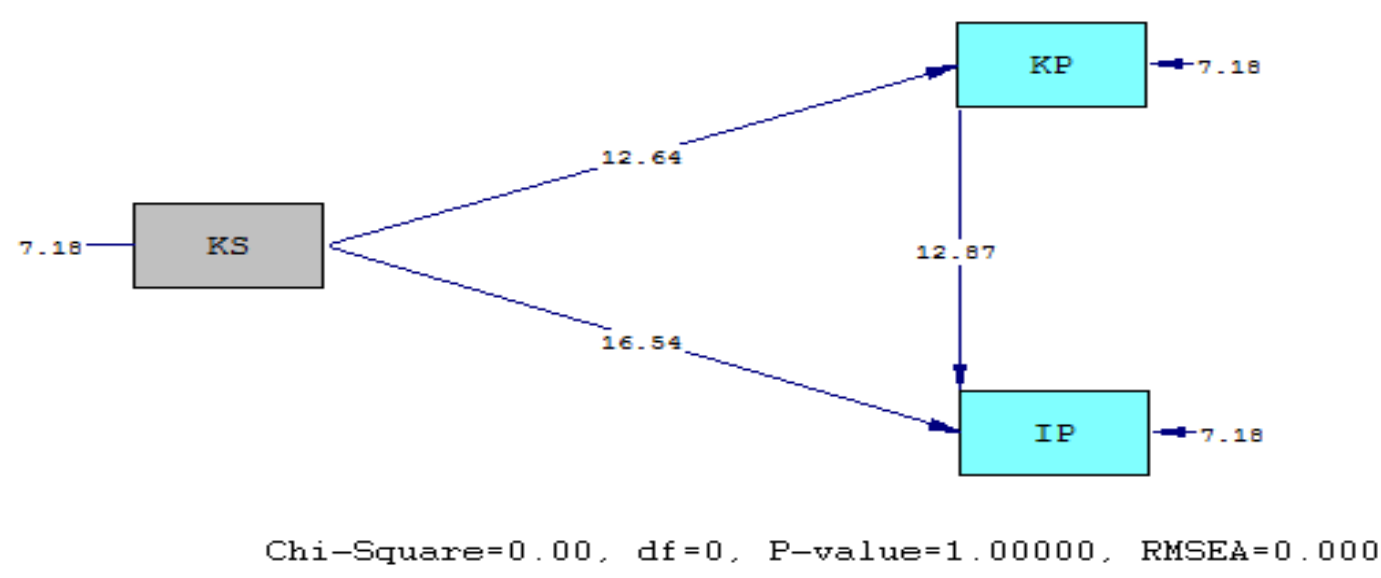

Gambar 6. T-value

Gambar 6 merupakan T-VALUE untuk menentukan ada pengaruh atau tidak kualitas sistem terhadap kepuasan pengguna, kepuasan pengguna terhadap intensitas pengguna dan kualitas sistem terhadap kepuasan pengguna. Sehingga dapat diketahui besarnya pengaruh antar variabel penelitian berdasarkan kerangka konseptual. Analisis jalur akan memberikan penjelasan mengenai besarnya pengaruh serta signifikansi pengaruh antar variabel. Suatu koefisien path dinyatakan berpengaruh signifikan jika mempunyai T-value $>1,96$. Berikut Tabel 6 adalah hasil analisis jalur antar variabel berdasarkan output pada program LISREL 9.30:

Tabel 7 Pengukuran pada model 1:

\begin{tabular}{|c|c|c|c|c|}
\hline \multirow[t]{2}{*}{ VARIABEL } & \multicolumn{4}{|c|}{ STANDARDIZED SOLUTION } \\
\hline & $\begin{array}{l}\text { Loading } \\
\text { Factor } \\
(\lambda \geq 0,50)\end{array}$ & Ket. & $\begin{array}{c}\text { Signifikansi } \\
(T \text {-value = sig } \\
=\text { berwarna } \\
\text { hitam })\end{array}$ & Ket. \\
\hline KS - KP & 0,78 & Valid & 12,64 & Signifikan \\
\hline KP - IP & 0,45 & Tidak valid & 12,87 & Signifikan \\
\hline KS - IP & 0,58 & valid & 16,54 & signifikan \\
\hline \multicolumn{5}{|l|}{ Keterangan: } \\
\hline KS : & as sistem & & & \\
\hline $\mathrm{KP}$ & san pengguna & & & \\
\hline IP & as pengguna & & & \\
\hline
\end{tabular}

Berdasarkan tabel diatas dapat dijelaskan bahwa:

Koefisien standar KS terhadap KP adalah 0,78. Artinya jika nilai KS bertambah sebesar 1 kali standar deviasi, maka nilai KP akan bertambah 0,78 kali standar deviasi. Nilai hitung t-value jalur ini adalah 12,64 > T-standar 1,96 sehingga signifikan. Dengan demikian dapat disimpulkan bahwa KS mempunyai pengaruh terhadap KP.

Koefisien standar KP terhadap IP adalah 0,45. Artinya jika nilai KS bertambah sebesar 1 kali standar deviasi, maka nilai IP akan bertambah 0,45 kali standar deviasi. Nilai hitung t-value jalur ini adalah 12,87 > T-standar 1,96 sehingga signifikan. Dengan demikian dapat disimpulkan bahwa KPmempunyai pengaruh terhadap IP.

Koefisien standar KS terhadap IP adalah 0,58. Artinya jika nilai KS bertambah sebesar 1 kali standar deviasi, maka nilai IP akan bertambah 0,58 kali standar deviasi. Nilai hitung t-value jalur ini adalah 16,58 > T-standar 1,96 sehingga signifikan. Dengan demikian dapat disimpulkan bahwa KS mempunyai pengaruh signifikan terhadap IP. 
Tabel 8. indikator Goodness-of-Fit

\begin{tabular}{lccc}
\hline \multicolumn{1}{c}{ Ukuran GFT } & Kriteria Uji & $\begin{array}{c}\text { Indikator } \\
\text { model }\end{array}$ & Keterangan \\
\hline P- value & $\geq 0,05$ & 1,000 & Perfect fit \\
RMSEA & $\leq 0,08$ & 0,000 & Perfect fit \\
GFI & $\geq 0.90$ & Mendekati 1 & fit \\
AGFI & $\geq 0.90$ & Mendekati 1 & fit \\
CFI & $\geq 0.90$ & Mendekati 1 & Fit \\
NFI & $\geq 0.90$ & Mendekati 1 & Fit \\
NNFI & $\geq 0.90$ & Mendekati 1 & Fit \\
\hline
\end{tabular}

Tabel 8 dapat dilihat bahwa indikator goodness of fit dari model ini, menunjukkan hasil uji yang memenuhi kriteria model fit.

\section{KESIMPULAN}

Dari hasil uji analisis jalur diatas dapat dilihat bahwa indikator goodness of fit dari model ini, menunjukkan hasil uji yang memenuhi kriteria model fit. Dengan demikian dapat ditarik kesimpulan bahwa model yang diusulkan fit dengan data. Artinya model mampu menghasilkan matriks kovariansi/matriks korelasi populasi yang sama dengan matriks kovariansi/matriks korelasi data sampel. Maka hasil estimasi parameter model dapat diandalkan untuk diberlakukan terhadap populasi.

Berdasarkan uraian diatas peneliti dapat mengetahui bahwa efek langsung standarized solution KS-IP=0,58. Sedangkan efek tidak langsung standarized solution KS-KP$\mathrm{IP}=0,78 \mathrm{x} 0,45=0,351$. Sehingga dapat ditarik kesimpulan bahwa dari analisis jalur bahwa efek langsung standarized solution KS-IP=0,58 > efek tidak langsung standarized solution KS-KP$\mathrm{IP}=0,78 \times 0,45=0,351$. Yang berarti memiliki makna jalur KS-IP lebih baik/lebih besar nilainya daripada KS-KP-IP.

\section{SARAN}

Pada penelitian ini hanya terbatas pada variabel Kualitas Sistem, Kepuasan Pengguna dan Intensitas Pengguna, diharapkan penelitian selanjutnya dapat menambah variabel tersebut dengan variabel yang lain sehingga dapat memberikan hasil evaluasi yang lebih baik lagi.

\section{UCAPAN TERIMA KASIH}

Ucapan terima kasih kepada Politeknik Negeri Jember atas pendanaan penelitian BOPTN 2017

\section{DAFTAR PUSTAKA}

[1] I Gusti Ngurah Agung Suaryana, I Gst Ayu Eka Damayanthi, Ni K. Lely Aryani Merkusiwati. Kualitas Dan Kepuasan Pengguna Terhadap Sistem Informasi Akademik Berbasis Web. Jurnal Ilmiah Akuntansi dan Bisnis, Vol. 11, No. 2, Juli 2016

[2] Abdi, Azazi. 2016 Uji Empiris Model Kesuksesan Sistem Informasi Pengelolaan Keuangan Daerah (Sipkd) Di Pemerintah Kota Bukittinggi Dengan Menggunakan Delone \& Mclean Information System Success Model. Masters thesis, Universitas Andalas.

[3] Suharno Pawirosumarto. Pengaruh Kualitas Sistem, Kualitas Informasi, Dan Kualitas Layanan Terhadap Kepuasan Pengguna Sistem E-Learning. Jurnal Ilmiah Manajemen, Volume VI, No. 3, Okt 2016

[4] Dony Setiawan Hendyca Putra, Meilana Siswanto. Pengaruh Kualitas Sistem, Kualitas Informasi dan Kualitas Layanan Terhadap Kepuasan Pengguna Sistem Informasi 
Manajemen Rumah Sakit Daerah Kalisat Kabupaten Jember. Seminar Hasil Penelitian dan Pengabdian Masyarakat Dana BOPTN Tahun 2016, ISBN : 978-602-14917-3-7

[5] Djuhono Tan, Suyatno, Siti Aliyah.Pengujian Kesuksesan Sistem Informasi Model Delone \& Mclean Pada Sektor Publik.University Research Colloquium 2015. ISSN 2407-9189

[6] Sugiyono. 2015. Metode Penelitian Pendidikan. Yogyakarta: Pustaka Pelajar.

[7] Notoadmojo. 2015. Metode Penelitian Kesehatan. Jakarta: Rineka Cipta.

[8] Jogiyanto. 2010. Model Kesuksesan Sistem Teknologi Informasi. Yogyakarta: Andi. 